\title{
EVIDENCE LEVEL OF THE PLACEMENT OF SCREWS OUTSIDE PEDICLE IN THORACIC AND LUMBAR SPINE
}

\author{
NÍVEL DE EVIDÊNCIA SOBRE A COLOCAÇÃO DE PARAFUSOS FORA DO PEDÍCULO \\ NA COLUNA TORÁCICA E LOMBAR
}

\section{NIVEL DE EVIDENCIA DE LA COLOCACIÓN DE TORNILLOS FUERA DEL PEDÍCULO EN COLUMNA TORÁCICA Y LUMBAR}

Gabriel Aldama Bustos ${ }^{1}$, Alfredo Javier Moheno Gallardo², Eulalio Elizalde Martínez²

1. Hospital de Especialidades UMAET1 Bajío IMSS, Mexico.

2. Hospital de Ortopedia de la UMAE “Dr. Victorio de la Fuente Narváez" IMSS, Mexico.

\begin{abstract}
International recommendations in spine surgery require reproducible, safe and effective procedures. The placement of pedicle screws is technically demanding and relies on different methods of support, which result a high rate of complications related to suboptimal screw placement, with reports ranging from $15.7 \%$ to $40 \%$ according to Hansen-Algenstaedt $\mathrm{N}$ and Koktekir E in separate studies. This study carried out a systematic review of existing literature to identify the level of evidence of the placement of pedicle screws outside the pedicle in thoracic and lumbar spine. For the systematic review, a search of the existing literature, based on the use of MeSH terms in PubMedMedline, Ovid, The Cochrane Library, MedicLatina, Elsevier, and EBSCO databases. According to the literature found, most authors agree that the placement of screws outside the pedicle itself does not represent a serious complication or that requires repositioning in a second surgery even when they are found to have a violation up to $50 \%$ of the medial wall of the pedicle. However, they agree that repositioning should be immediate if it is shown with imaging studies such as MRI and CT that endangers vascular and/or neurological structures, or are associated with biomechanical alterations of the spine. Level of Evidence II; Systematic Review of studies level II.
\end{abstract}

Keywords: Pedicle Screw; Spinal Cord; Spine.

\section{RESUMO}

As recomendações internacionais em cirurgia da coluna vertebral, forçam a execução de procedimentos reprodutíveis, seguros e eficazes. A colocação de Parafusos transpediculares é tecnicamente exigente e se baseia em métodos diferentes de apoio, dando como resultado uma alta taxa de complicações relacionadas com a colocação sub-optima de parafusos, apresentando relatórios variando de 15,7\% para 40\%, de acordo com Hansen-Algenstaedt N e Koktekir E em estudos independentes. Este estudo é uma revisão sistemática da literatura existente, identificando o nível de evidência sobre a colocação de parafusos transpediculares fora do pedículo em coluna torácica e lombar. Para a revisão sistemática, foi conduzida uma pesquisa da literatura, baseada no uso de termos MeSH, nos bancos de dados: PubMed-Medline, Ovid, The Cochrane Library, MedicLatina, Elsevier e EBSCO. De acordo com o encontrado, a maioria dos autores concordam que a colocação dos parafusos fora pedículo em si não representem uma complicação grave e não obriga a realocação deles em um segundo tempo cirúrgico, mesmo que eles apresentam uma violação de até $50 \%$ da parede medial do pedículo. No entanto, concordam que o posicionamento deve ser imediato se pôr em perigo as estruturas vasculares ou neurológicas ou estarem associados a alterações na biomecânica vertebral. Nível de Evidência II; Revisão Sistemática do nível de estudos II

Descritores: Parafusos Pediculares; Médula espinal; Coluna vertebral.

\section{RESUMEN}

Las recomendaciones internacionales en cirugía de columna obligan a realizar procedimientos reproducibles, seguros y eficaces. La colocación de tornillos trans-pediculares es demandante técnicamente y se apoya en diversos métodos de asistencia, que dan como resultado un alto índice de complicaciones relacionadas con la colocación subóptima de los tornillos, con reportes que van desde el 15,7\% al 40\% según Hansen-Algenstaedt $N$ y Koktekir E en estudios independientes. Este estudio realiza una revisión sistemática de la literatura existente, donde se identifica el nivel de evidencia de la colocación de tornillos transpediculares fuera del pedículo en la columna torácica y lumbar. Para la revisión sistemática se realizó una búsqueda de la bibliografía existente, basada en la utilización de términos MeSH, en la base de datos: PubMed-Medline, Ovid, The Cochrane Library, MedicLatina, Elsevier y EBSCO. De acuerdo con la literatura encontrada, la mayoría de los autores concuerdan en que la colocación de tornillos fuera de pedículo en sí misma no representa una complicación grave o que requiera recolocación en un segundo tiempo quirúrgico, aun cuando se encuentren con una violación de hasta el 50\% de la pared medial del pedículo; sin embargo concuerdan en que la recolocación debe ser inmediata si se demuestra con estudios de imagen como IRM y TAC que pone en riesgo estructuras vasculares y/o neurológicas, o se asocian a alteraciones biomecánicas de la columna vertebral. Nivel de Evidencia II; Revisión sistemática de Estudios de Nivel II.

Descriptores: Tornillos Pediculares; Médula espinal; Columna vertebral. 


\section{INTRODUCTION}

Most high-energy accidents involve spine injuries and the most frequent are of the thoracic and lumbar spines. This has posed a challenge for spine surgeons regarding decisions about both the surgical approach and the configuration of the instrumentation. ${ }^{1-5}$

International recommendations mandate reproducible, safe, and effective procedures. . $^{6}$

Pedicle screw placement techniques are demanding. Transoperative navigation support is limited by its high cost. The use of a fluoroscope overexposes the health personnel and the patient to radiation and offers only limited assistance at the moment of screw placement. Anatomic vertebral modifications, especially in patients with degenerative pathology, result in a rate of complications related to suboptimal placement of the screws..$^{9,10}$ Therefore, it is important to identify the level of evidence in the medical literature about the placement of pedicle screws outside of the pedicle as a complication and the level of application of the results systematically in the medical literature in patients submitted to thoracic or lumbar instrumentation surgery, ${ }^{11,12}$ as well as its significance in the medical-legal sphere. ${ }^{1,2,6-8,13-22}$

\section{METHODS}

A systematic review of the existing literature was conducted in which the level of evidence about the placement of pedicle screws outside the pedicle in the thoracic and lumbar spines was identified. It was authorized by the Institutional Review Board as No. 3401 and COFEPRIS Registration No. 13 Cl 09005 221, "Dr. Victorio de la Fuente Narváez" Orthopedic Hospital of the UMAE, IMSS, Mexico, who assigned Registration No. R-20163401-50 to the project. For the systematic review a search of the existing literature was performed, based on the use of MeSH terms in the PubMed-Medline, Ovid, The Cochrane Library, MedicLatina, Elsevier, and EBSCO databases. The MeSH terms used were Pedicle Screw Complication, Misplacement, Thoracic Spine, and Lumbar Spine.

The results were evaluated in a qualitative, retrospective, cross-sectional, observational, systematic review study, according to the recommendations of the Cochrane Group, establishing the level of evidence for the placement of pedicle screws outside of the pedicle in the thoracic and lumbar spines, including a description of the variables, a homogeneity analysis, and the identification and analysis of interobserver concordance, according to the Jada scale, the kappa value, the intraclass correlation coefficient (ICC), considering values $\geq 0.80$ and $p<0.05$ as reliable.

\section{RESULTS}

We obtained 112 articles, from which we initially selected 46 . After the first filtering, we ended up with 22 articles relating to the placement of pedicle screws outside the pedicle, which met the selection criteria and completed the full text sample.

Two observers participated independently in the qualification, methodological evaluation, level of evidence, and grade of recommendation, in accordance with Sackett's classification of levels of evidence, disagreeing on three articles regarding the level of evidence and grade of recommendation and a third observer was used to determine the proper classification for those articles.

Of the 19 articles included, twelve (63\%) were from the United States of America, two (11\%) from China, and one each (5\%) from the United Kingdom, Turkey, Austria, Switzerland, and Greece. (Figure 1).

There is very little literature of high quality and good methodological design on the subject of the level of evidence and grade of recommendation of placement of pedicle screws outside the pedicle in the thoracic and lumbar spine as a complication. The results of our review indicate level of evidence "4" (Figure 2) and grade of recommendation " $\mathrm{C}$ ", with a "favorable, but not conclusive recommendation". (Figure 3)

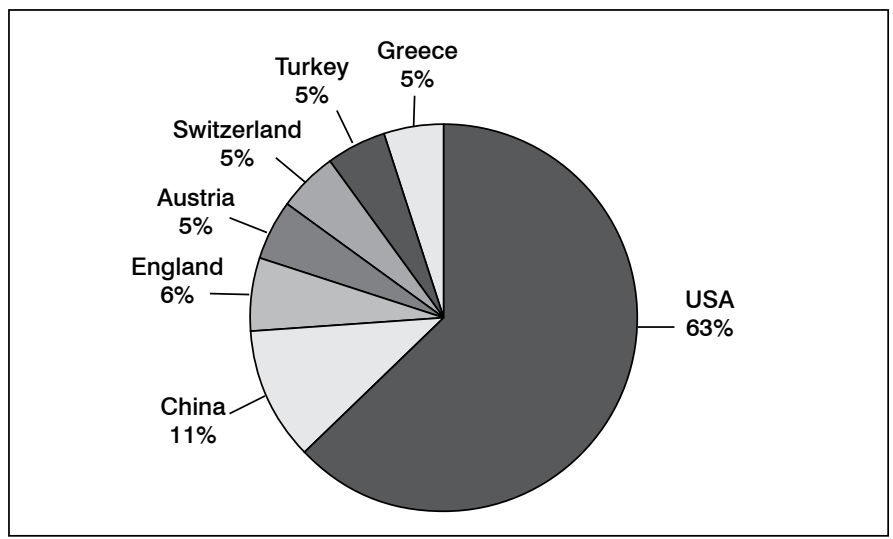

Figure 1. Distribution by country.

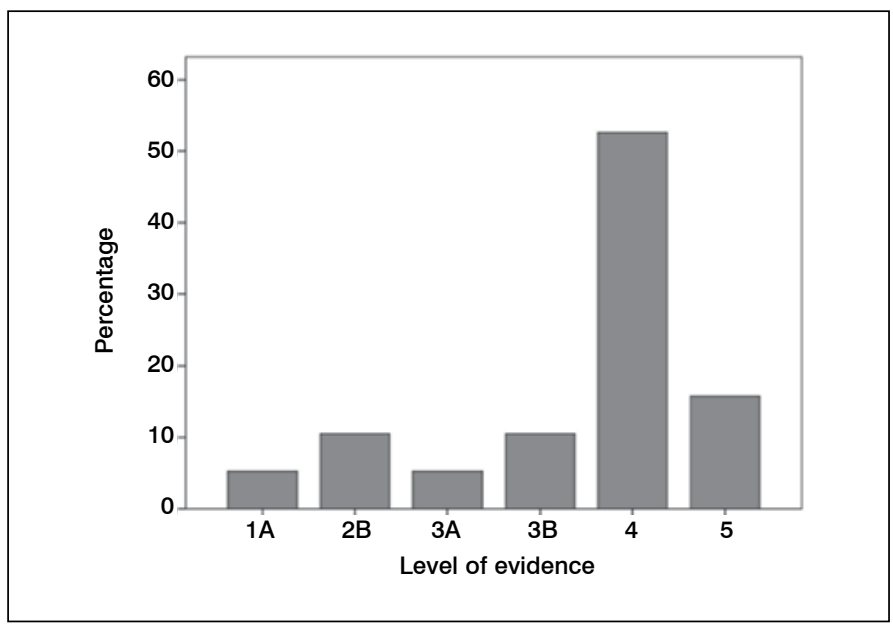

Figure 2. Level of evidence.

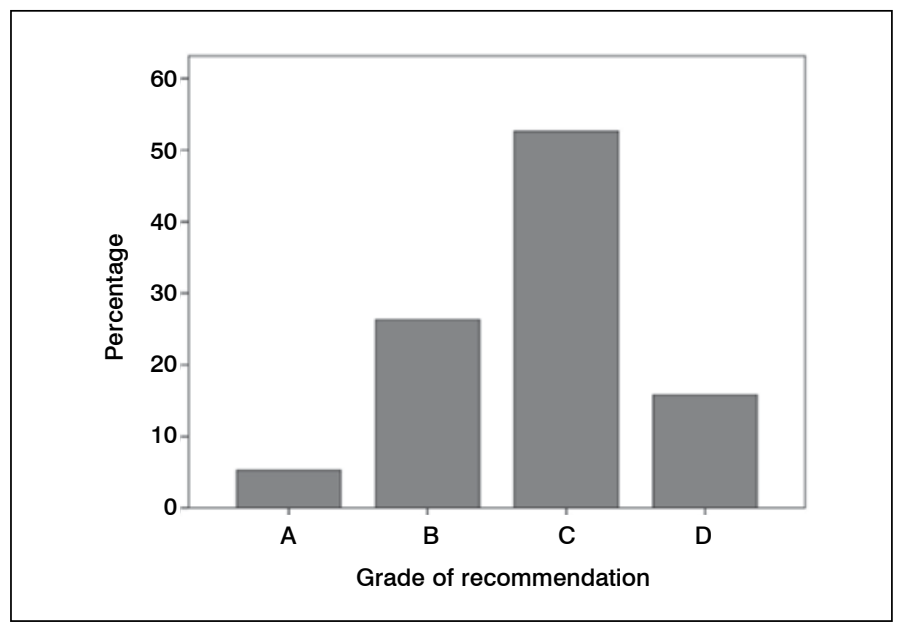

Figure 3. Grade of recommendation.

\section{DISCUSSION}

The posterior lumbar interbody fusion (PLIF) technique has become an important component of modern spine pathology treatment. Fixation with pedicle screws is an important method for internal thoracic and lumbar spine fixation. The screw-pedicle interface is a biomechanically superior fixation site as compared to the hook-lamina or wire-lamina interface. ${ }^{3-5}$ However, there is a problem associated with transpedicular fixation: the pedicle is the strongest location, but it is not the widest part of the vertebrae. This factor is fundamental in the placement of the screws in the 
pedicles. A significant rate of screws placed outside of the pedicle and the resulting complications has been reported and extrapedicular placement of the screws is considered by some authors as a catastrophic failure of the procedure, In general, there is very little literature published by the other surgeons about these situations and what exists is of poor quality and poor methodological design. Thus, we consider it important to conduct a study that establishes a benchmark to determine the true severity of placement of the pedicle screws outside of the pedicle and to encourage new studies with a higher level of evidence than those published to date.

\section{CONCLUSIONS}

In disagreement with the literature found, most of the authors agree that screw placement outside of the pedicle by itself is not a serious complication or one that requires them to be repositioned in a second surgery, since this would be an additional medical risk to the patient and would increase the costs incurred by the health system, even when it would be a grade III violation of the medial wall of the pedicle. However, we agree that the repositioning of these screws should be immediate if imaging studies such as MRI and CAT studies show that they are putting vascular and/or neurological structures at risk or they are associated with biomechanical alterations of the spine, even if there is a grade II violation of the medial wall of the pedicle. The screws that present a grade I violation of the pedicle, and most of the grade II violations are rarely accompanied by vascular and nerve lesions, so the grade of recommendation for replacement of these screws is D. For grade III and IV screws, the grade of recommendation for screw replacement is $\mathrm{C}$ and for grade II, III, and IV screws the grade of recommendation for replacement of the screws is $A$.

\section{ACKNOWLEDGEMENTS}

To the great teachers from whom I have had the good fortune to learn and my wife who pushes me forward.

All authors declare no potential conflict of interest related to this article.

CONTRIBUTION OF THE AUTHORS: Each author made significant individual contributions to this manuscript. GAB (0000-0002-3955-3206)* was the main contributor to the intellectual concept of the study and the writing of the manuscript, as well as to the review and the bibliographical research. AJMG (0000-0003-2869-0405)* and EEM (0000-0002-5397-3557)* evaluated and analyzed the data and conducted the statistical analysis. GAB, AJMG, and EEM made significant contributions to the review and the writing of the final manuscript. *ORCID (Open Researcher and Contributor ID).

\section{REFERENCES}

1. Tubert-Brohman I, Sherman W, Repasky M, Bruming T. Imbard docking of polypeptides with glide. J Chem Inf Model. 2013;53(7):1689-99.

2. Aebi M. Transpedicular Fixation. Indication, Techniques and Complications. Current Orthopaedics. 1991:5(2):109-16.

3. Açikbas SC, Arslan FY, Tuncer MR. The effect of transpedicular screw misplacement on late spinal stability. Acta Neurochir (Wien). 2003;145(11):954-5.

4. Nevzati E, Marbacher S, Soleman J, Perrig WN, Diepers M, Khamis A et al. Accuracy of pedicle screw placement in the thoracic and lumbosacral spine using a conventional intraoperative fluoroscopy-guided technique: A national neurosurgical education and training center analysis of 1236 consecutive screws. World Neurosurg. 2014:82(5):866-71.

5. Gelalis ID, Paschos NK, Pakos EE, Politis AN, Arnaoutoglou CM, Karageorgos AC et al. Accuracy of pedicle screw placement: a systematic review of prospective in vivo studies comparing free hand, fluoroscopy guidance and navigation techniques. Eur Spine J. 2012;21(2):247-55

6. Bernatz JT, Anderson PA. Thirty-day readmission rates in spine surgery: systematic review and meta-analysis. Neurosurg Focus. 2015;39(4):E7.

7. Tsai TT, Lee SH, Niu CC, Lai PL, Chen LH, Chen LH. Unplanned revision spinal surgery within a week: a retrospective analysis of surgical causes. BMC Musculoskelet Disord. 2016;17:28.

8. McCormack RA, Hunter T, Ramos N, Michels R, Hutzler L, Bosco JA. An Analysis of Causes of Readmission After Spine Surgery. Spine (Phila Pa 1976). 2012;37(14):1260-6.

9. Raley DA, Mobbs RJ. Retrospective Computed Tomography Scan Analysis of Percutaneously Inserted Pedicle Screws for Posterior Transpedicular Stabilization of the Thoracic and Lumbar Spine. Spine (Phila Pa 1976). 2012;37(12):1092-100.

10. Hansen-Algenstaedt N, Chiu CK, Chan CY, Lee CK, Schaefer C, Kwan MK. Accuracy and Safety of Fluoroscopic Guided Percutaneous Pedicle Screws in Thoracic and Lumbosacral Spine. Spine (Phila Pa 1976). 2015;40(17):E954-63.

11. Faraj AA, Webb JK. Early complications of spinal pedicle screw. Eur Spine J. 1997;6(5):324-6
12. Koktekir E, Ceylan D, Tatarli N, Karabagli H, Recber F, Akdemir G. Accuracy of fluoroscopically-assisted pedicle screw placement: Analysis of 1,218 screws in 198 patients. Spine J. 2014;14(8):1702-8.

13. Li N, He D, Xing Y, LVY,Tian W. The effect of lateral wall perforation on screw pull-out strength: a cadaveric study. J Orthop Surg Res. 2015;10:6.

14. Cardoso MJ, Dmitriev AE, Helgeson M, Lehman RA, Kuklo TR, Rosner MK. Does superior-segment facet violation or laminectomy destabilize the adjacent level in lumbar transpedicular fixation? An in vitro human cadaveric assessment. Spine (Phila Pa 1976). 2008;33(26):2868-73.

15. Tschoeke SK, Gahr P, Krug L, Kasper AS, Heyde CE, Ertel W. Late diagnosis of pedicle screw malplacement with perforation of the thoracic aorta after posterior stabilization in a patient with multiple myeloma: case report. Spine (Phila Pa 1976). 2011;36(13):E886-90.

16. Parker SL, Amin AG, Santiago-Dieppa D, Liauw JA, Bydon A, Sciubba DM, et al. Incidence and clinical significance of vascular encroachment resulting from freehand placement of pedicle screws in the thoracic and lumbar spine. Spine (Phila Pa 1976). 2014;39(8):683-7.

17. Hicks JM, Singla A, Shen FH, Arlet V. Complications of Pedicle Screw Fixation in Scoliosis Surgery: A Systematic Review. Spine (Phila Pa 1976). 2010:35(11):E465-70. 18.

18. Guillen PT, Knopper RG, Kroger J, Wycliffe ND, Danisa OA, Cheng WK. Independent assessment of a new pedicle probe and its ability to detect pedicle breach: a cadaveric study. J Neurosurg Spine. 2014;21(5):821-5.

19. Wang VY, Chin CT, Lu DC, Smith JS, Chou D. Free-hand thoracic pedicle screws placed by neurosurgery residents: A CT analysis. Eur Spine J. 2010;19(5):821-7.

20. Sackett DL, Wennberg JE. Choosing the best research design for each question. BMJ $\mathrm{Br}$ Med J. 1997;315(7123):1636

21. Jadad AR, Moore RA, Carroll D, Jenkinson C, Reynolds DJ, Gavaghan DJ, et al. Assessing the quaility of reports of randomized clinical trials: Is blinding necessary? 1996:17(1):1-12.

22. Fleiss JL. Measuring nominal scale agreement among many raters. Psychol Bull. $1971 ; 76(5): 378-82$ 